\title{
Kelch-Like ECH-Associated Protein 1
}

National Cancer Institute

\section{Source}

National Cancer Institute. Kelch-Like ECH-Associated Protein 1. NCI Thesaurus. Code C112107.

Kelch-like ECH-associated protein $1(624 \mathrm{aa}, \sim 70 \mathrm{kDa}$ ) is encoded by the human KEAP1 gene. This protein is involved in ubiquitin-mediated protein degradation. 